\title{
Effect of Corporate Social Responsibility Disclosure on Financial Performance
}

\author{
Hang Thi Thuy Ta \\ University of Labor and Social Affairs, Vietnam \\ Ngoc Thi Bui (Corresponding author) \\ University of Labor and Social Affairs, Vietnam \\ Room No. 44, A8, 120 Hoang Quoc Viet Street, Cau Giay District, Hanoi, Vietnam \\ E-mail: buithingoc.ldxh@gmail.com
}

Received: Jan. 3, 2018 Accepted: Feb. 22, 2018 Published: June 1, 2018

doi:10.5296/ajfa.v10i1.12592 URL: https://doi.org/10.5296/ajfa.v10i1.12592

\begin{abstract}
Corporate social responsibility is the commitment by business to contribute to sustainable development through the balance of three factors which are economic, social and environmental factor. Enterprises carry out corporate social responsibility through specific activities such as controlling environmental pollution, natural resource conservation, energy conservation, employment safety, especially supporting and developing community. Corporate social responsibility disclosure plays an important role in implementation of corporate social responsibility, promotion of business's image and creation of good impression to stakeholders. This study was conducted using a two-step Generalized Method of Moment (GMM) technique with instrumental variables for balanced panel data through the annual reports and sustainable development reports of 43 enterprises listed on the Vietnam stock market from 2006 to 2016 (473 observations). The results showed that the level of corporate social responsibility disclosure has a positive effect on return on assets. This study has important implications for enterprises in terms of investing activities and corporate social responsibility disclosure.
\end{abstract}

Keywords: Corporate social responsibility disclosure, financial effectiveness, return on assets (ROA) 


\section{Introduction}

Sustainable development is the trend of the times and businesses cannot afford to ignore this trend. The practice and disclosure of corporate social responsibility information is considered a tool for businesses to communicate the activities of sustainable development of society. Gray et al. (1995) provided that corporate social responsibility disclosure is the process of providing information about corporate activities affecting environment and society. Enterprises are accountable for such information to related parties, apart from financial information publicized to shareholders. Non-governmental organizations and nations have introduced standards and regulations to guide firms to establish and display corporate social responsibility information, including the United Nations Global Compact (UNGC), International Finance Corporation (IFC), Global Reporting Initiative (GRI), International Integrated Reporting Council (IIRC), The Sustainability Accounting Standards Board (SASB). Depending on conditions, legal regulations and needs, enterprises can disclose corporate social responsibility information in accordance with standard or legal requirements. According to the above standards, corporate social responsibility may include following key information:

Environment: Environmental policies or environmental concerns of enterprises, environmental pollution control in business operations, conservation of natural resources, prevention and remedies for environmental consequences of the manufacturing process or natural resources, information about emissions, discharge of waste water, waste treatment.

Energy: Information about a company's energy policies, energy conservation in the course of business operations, utilization of waste materials for energy production, research towards energy savings by reprocessing products.

Employment: Information regarding regulations and standards on labor safety, working conditions, health care for workers, training, financial support for housing, information about the daily allowance for employees, maternity leaves, holidays, information regarding policies for seasonal/ contractual employees or plan of hiring seasonal/ contractual employees, provision of information regarding recruitment/ jobs for women or ethnic minorities or special interest groups.

Supporting and developing community: Information about donations with money, artifacts or services of enterprises to support community activities, events, arts, sports, funding for health projects and providing information related to public health.

Products: Researching and developing products to improve product quality and to meet safety standards.

With increasing community interest in corporate social responsibility, many studies in the world have been conducted to verify the impact of corporate social responsibility disclosure to business efficiency such as Mahoney \& Roberts (2007), Makni et al. (2009), Saleh et al. (2011), Tjia \& Setiawati (2012), Vurro \& Perrini (2011), Lu et al. (2015), Strouhal et al. (2015), Jitaree (2015). Impacts are expressed in a variety of indicators, such as the impact on a firm's share price, return on assets (ROA), return on equity (ROE), market value compared to book value Tobin'Q, revenues of enterprises. Although these studies had different results, the majority 
concluded that corporate social responsibility disclosure has a positive impact on business efficiency. Several studies had reported negative results Makni et al (2009) and in some cases there were not statistically significant Strouhal et al. (2015), Khlif et al. (2015), Tjia\& Setiawati (2012). In Vietnam, some studies have investigated the current state and benefits of corporate social responsibility disclosure. The results showed that Corporate Social Responsibility disclosure increases the value of enterprises Tobin'Q Nguyen et al. (2015), Nguyen \& Trinh (2016), increases the return on assets Ho \& Ho (2017). However, research time was short and these studies used panel data with the Fixed Effects Model (FEM) and the Random Effects Model (REM) for the survey. Using these estimation methods will not be reliable if endogenous phenomena exists in the model. To overcome this situation, it is necessary to use other estimation methods and extend research time. It is critical to ensure reliability of the study on the effect of corporate social responsibility disclosure on corporate financial performance. For this purpose, in this study the authors used a two-step Generalized method of moment (GMM) for balanced panel data with 473 observations of 43 firms over a period of 11 years from 2006 to 2016 .

\section{Theoretical foundations and hypothesis}

From an academic point of view, many researchers have investigated the theoretical basis to explain the relationship between practice and disclosure of corporate social responsibility and financial performance of firms in different contexts. In this study, the authors used two theories to explain the relationship between corporate social responsibility disclosure and corporate financial performance.

\section{Stakeholder theory}

Edward (1984) was the first to propose the stakeholder theory. He supposed that the goal of a business is to meet the needs of stakeholders who may influence or be influenced by the attainment of their goals. If this is done a firm's profits will be generated. Based on the stakeholder theory in strategic management, Ullmann (1985) presented 8 scenarios to explain the differences in the results of the relationship between Corporate social responsibility disclosure and corporate financial performance. According to him, the relationship between corporate social responsibility disclosure and corporate financial performance depends on other factors such as the power of stakeholders and management strategies. He provided that corporate financial performance has a positive impact on social efficiency and corporate social responsibility disclosure.

\section{Legitimacy theory}

Legitimacy theory is derived from the concept of organizational legitimacy, Dowling \& Pfeffer (1975) defined: "An entity can exist when its value system is congruent with the value system of the larger social system. When there is a real or potential disparity between two value systems, the legitimacy of that entity is threatened".

Developing legitimacy theory, Deegan (2002) supposed that enterprises and society have a continuous and interconnected relationship. For example, companies buy human resources, raw materials from society, conversely, companies provide products and services for society, 
discharge waste from the production process of enterprises to environment and society has to pay for the consequences. Enterprises try to control their legitimate existence to ensure capital flow, labor and customers, while avoiding the management activities of the government harming the business and boycotting products or other disruptive actions of competitors.

Stakeholder theory and legitimacy theory indicate that practice and disclosure of corporate social responsibility will lead to better financial performance. Conversely, in the case of good corporate financial performance, corporate social responsibility disclosure is also greater. Based on these theoretical foundations, the author constructed the following hypothesis:

H1: There is a positive relationship between social responsibility disclosure and financial performance.

\section{Methodology}

\subsection{Data collection}

Samples selected by the authors were non-financial companies listed on the stock market from 2006 to 2016. The reason why the author chose this period is because 2006 Vietnamese stock market boom with the appearance of the Hanoi Securities Trading Center in March 2005. The number of listed companies increased sharply. As of 31 December 2006, there were 193 companies listed on both exchanges (106 companies listed on Hochiminh Stock Exchange and 87 companies listed on Hanoi Stock Exchange).Financial and banking organizations were not chosen because information provided by these companies is significantly different from other types of enterprises. The last sample was 43 listed companies on the Vietnam stock market randomly selected by the elimination of financial firms, creditors, and those were not listed companies during the research period as well as companies which the authors could not collect annual reports or sustainable development reports. Thus, 43 enterprises were surveyed for 11 years with the balanced panel data with a total observations of $43 \times 11=473$. Shown in table1.

Table 1. List of companies surveyed

\begin{tabular}{|l|l|l|}
\hline & Code & \\
\hline 1 & AGF & An Giang Fisheries \\
\hline 2 & BHS & Bien Hoa Sugar \\
\hline 3 & BMC & Binh Dinh Minerals \\
\hline 4 & BMP & Binh Minh Plastics \\
\hline 5 & CAN & Halong Canfoco \\
\hline 6 & CII & Ho Chi Minh Infrastructure \\
\hline 7 & CLC & Cat Loi Tobacco \\
\hline 8 & CYC & Chang Yih Ceramic \\
\hline 9 & DHA & Hoa An Stones and Materials \\
\hline 10 & DHG & Hau Giang Pharmaceutical \\
\hline 11 & DMC & DOMESCO Medical \\
\hline 12 & DTT & Do Thanh Technology Corp. \\
\hline 13 & FPT & FPT Group \\
\hline
\end{tabular}




\begin{tabular}{|l|l|l|}
\hline 14 & GIL & Binh Thanh Im-export \\
\hline 15 & GMD & Gemadept \\
\hline 16 & HTV & Ha Tien Transport \\
\hline 17 & IMP & Imexpharm Pharmaceutical \\
\hline 18 & ITA & Tan Tao Industrial Park \\
\hline 19 & KDC & Kinh Do Corporation \\
\hline 20 & KHA & Khanh Hoi Investment and Services \\
\hline 22 & KHP & Khanh Hoa Power \\
\hline 23 & MCP & My Chau Printing and Packaging \\
\hline 24 & PGC & Petrolimex Gas \\
\hline 25 & PJT & Petrolimex Tanker \\
\hline 26 & PPC & Phuong Nam Cultural \\
\hline 27 & REE & Pha Lai Thermal Power \\
\hline 28 & SFC & Saigon Fuel Co. \\
\hline 29 & SFI & Sea and Air Freight International \\
\hline 30 & SGH & Saigon Hotel Corp. \\
\hline 31 & SJD & Can Don Hydro Power \\
\hline 32 & SMC & SMC Trading and Invm't \\
\hline 33 & SSC & Southern Seed JSC \\
\hline 34 & TAC & Tuong An Vegetable Oil \\
\hline 35 & TDH & Thu Duc House \\
\hline 36 & TNA & Thien Nam Trading and Exim \\
\hline 37 & TS4 & Seafood No 4 \\
\hline 38 & TYA & Taya (Vietnam) electric wire \& cable \\
\hline 39 & VGP & Vegetexco Port \\
\hline 40 & VIP & Viet Nam Petroleum Transport \\
\hline 41 & VIS & Vietnam - Italy Steel \\
\hline 42 & VNM & Vinamilk \\
\hline 43 & VTC & VTC Telecom \\
\hline
\end{tabular}

\subsection{Determining and measuring variables}

\subsubsection{Corporate social responsibility disclosure variable}

In this study, the author measured corporate social responsibility disclosure according to content analysis method based on annual reports and sustainable development reports of companies. The analyzing process was based on the list of indicators categorized in 4 groups shown in table2: information about environment (10 indicators), information about employment (12 indicators), information about supporting and developing community (8 indicators) and information about the products (5 indicators). The indicators of information were inherited from studies of Gunsanan et al. (2009), Jitaree (2015), Nguyen (2016) and according to circular $155 / 2015$ issued on $06 / 10 / 2015$ by Vietnamese Ministry of Finance on 
guidelines on information disclosure on the stock market.

Table 2. List of indicators of information about corporate social responsibility

\begin{tabular}{|c|c|}
\hline Symbol & Indicators (observed variables) \\
\hline ENV & Information about environment responsibility \\
\hline ENV 1 & $\begin{array}{l}\text { The enterprise complies with the law and regulations on prevention of } \\
\text { environmental pollution (including number of times and amount of fine for } \\
\text { violation of laws and regulations on environment) }\end{array}$ \\
\hline ENV 2 & $\begin{array}{l}\text { Information about pollution control activities in the course of business / The } \\
\text { report indicates that the polluting activities of enterprise has been and will be } \\
\text { reduced. }\end{array}$ \\
\hline ENV 3 & $\begin{array}{l}\text { Information about conservation of natural resources such as the use of } \\
\text { recycled materials, recycled glass, metal, oil, water, recycled paper }\end{array}$ \\
\hline ENV 4 & $\begin{array}{l}\text { Information about preventing and dealing with environmental consequences } \\
\text { due to production process or exploitation of natural resources, such as soil } \\
\text { improvement or reforestation. }\end{array}$ \\
\hline ENV 5 & $\begin{array}{l}\text { Information about strategies and supporting activities of enterprises towards } \\
\text { environmental protection / improving environment }\end{array}$ \\
\hline ENV 6 & Information about environmentally friendly design of infrastructure \\
\hline ENV 7 & Report information on emissions \\
\hline ENV 8 & Report information on discharging waste water \\
\hline ENV 9 & Report information on solid waste disposal \\
\hline ENV 10 & Report on information on environmental protection awards \\
\hline EMP & II. Information on responsibilities to employees \\
\hline EMP 1 & $\begin{array}{l}\text { Information about enterprises complying with safety standards and working } \\
\text { conditions for employees }\end{array}$ \\
\hline EMP 2 & Information about health care for employees \\
\hline EMP 3 & $\begin{array}{l}\text { Information about training, financial support of training courses for } \\
\text { employees }\end{array}$ \\
\hline EMP 4 & Information about recreational activities for employees \\
\hline EMP 5 & $\begin{array}{l}\text { Information about homestay accommodation or plan of homeownership, } \\
\text { food and other benefits for employees }\end{array}$ \\
\hline EMP 6 & Information on compensation for employees, maternity leave, holidays \\
\hline EMP 7 & Information about salaries, bonuses and other benefits for employees \\
\hline
\end{tabular}




\begin{tabular}{|c|c|}
\hline EMP 8 & Information about employee stock purchase plan \\
\hline EMP 9 & Information about qualifications and experiences of employees \\
\hline EMP 10 & Information on job stability of current and future employees \\
\hline EMP 11 & $\begin{array}{l}\text { Information about the relationship of enterprise with the union or workers } \\
\text { through the movement of culture, sports, emulation of production }\end{array}$ \\
\hline EMP 12 & Information about discrimination at workplace and jobs \\
\hline COM & III. Information about responsibilities with community \\
\hline COM 1 & $\begin{array}{l}\text { Information about charitable activities with money, products / services or } \\
\text { corporate employees participating in these activities, community events such } \\
\text { as sports, culture and arts. }\end{array}$ \\
\hline COM 2 & $\begin{array}{l}\text { Information about employment opportunities for students, special people } \\
\text { such as ethnic minorities, children of war invalids, disabled people, victims } \\
\text { of Agent Orange and those in difficult circumstances. }\end{array}$ \\
\hline COM 3 & $\begin{array}{l}\text { Information about sponsoring projects of community health and providing } \\
\text { health information to the Community / Supporting medical research }\end{array}$ \\
\hline COM 4 & $\begin{array}{l}\text { Information about establishing education funds or scholarships or } \\
\text { educational conferences }\end{array}$ \\
\hline COM 5 & $\begin{array}{l}\text { Information about supporting victims of natural disasters, family under } \\
\text { preferential treatment policy, victims of Agent Orange, contributions to } \\
\text { charity, sponsoring disabled children and orphan }\end{array}$ \\
\hline COM 6 & $\begin{array}{l}\text { Information about supporting the development of industries, economic } \\
\text { projects bringing benefits to the local }\end{array}$ \\
\hline COM 7 & Creating jobs and developing skills for local people \\
\hline COM 8 & $\begin{array}{l}\text { Contribution to building electricity infrastructure, roads, schools and stations } \\
\text { for localities }\end{array}$ \\
\hline CUS & IV. Information about responsibilities to customers \\
\hline CUS 1 & Information about product safety of enterprise \\
\hline CUS 2 & Information about product quality \\
\hline CUS 3 & Information about production and product development \\
\hline CUS 4 & $\begin{array}{l}\text { Commitment to quality, product safety and supporting when having trouble } \\
\text { using the products }\end{array}$ \\
\hline CUS 5 & $\begin{array}{l}\text { Building customer relationships, collecting contributions and resolving } \\
\text { customer complaints }\end{array}$ \\
\hline
\end{tabular}


Steps of the process: Corporate social responsibility is a complex field and there are many guiding standards, selecting ofstandards depends on economic conditions, laws and environment of each country. Therefore, in order to ensure the objectivity of the standard selection process, data collection and survey were conducted by two steps. Step 1 was conducting a survey of the 57 largest listed companies on the Vietnamese stock market, the survey year in2015. The purpose of this step was to adjust and select the appropriate indicators with conditions and characteristics of Vietnam. Step 2 was based on the indicators of information selected and corrected through step 1, the authors conducted the survey on 43 listed companies with 473 observations. This approach has been carried out by several authors, such as Branco \& Rodrigues (2006), Gunawan et al (2009), Saleh et al. (2011), Tjia \& Setiawati (2012), Bayoud et al (2012), Jitaree ).

Technical process: First the authors read reports and find information related to the indicators in the evaluation list. If an enterprise did not disclose the $\mathrm{i}^{\text {th }}$ indicator, the label is " 0 ", if the indicator was disclosed with general presentation or only with quantitative presentation without specific explanation, the label is " 1 ", if the indicator was disclosed with specific information about activities $\mathrm{k}$, the label is " 2 ". After determining the score for each indicator for each enterprise in each year, the level of corporate social responsibility disclosure (CSRD) under the average number specified is determined as follows:

$$
\mathrm{CSRDj}=\sum_{i}^{n} X \underline{\mathrm{ij}}
$$

In which:

CSRDj: indicator of information disclosure of $j^{\text {th }}$ enterprise

$\mathrm{Xij}=0 \mathrm{ifi}^{\text {th }}$ indicator of information is not disclosed in enterprise $\mathrm{j}$

$\mathrm{Xij}=1 \mathrm{ifi}^{\text {th }}$ indicator of information disclosed in enterprise $\mathrm{j}$ is general information or quantitative information without specific explanation

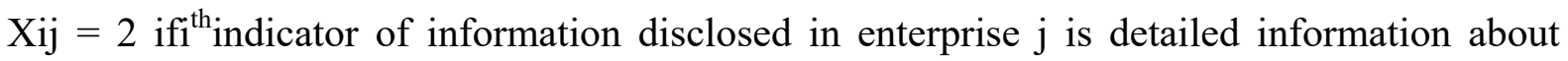
specific activities

\subsubsection{Financial performance variable}

Studies of authors such as Mahoney \& Roberts (2007), Makni et al. (2009), Platonova et al. (2016), Cheung \& Mak (2010), Jitaree (2015), Mohammed et al. (2016) used ROA as a measure of financial performance and verify the relationship between corporate social responsibility disclosure and corporate financial performance. Inheriting this research model, the author selected ROA as a measure of financial performance. ROA is determined by the following formula:

\section{Profit Before Tax \\ ROA $=$ Average Total Assets}

The reason why profit before taxes was used is because the corporate income tax rate in 
Vietnam during the period 2006 - 2016 varied from $28 \%, 25 \%, 22 \%$ and $20 \%$. Thus, to eliminate the effect of the corporate income tax rate on ROA, the author used profit before tax for analysis.

\subsubsection{Controlling variables}

Following variables are controlling variables of the model: corporate size, leverage (debts/equity), foreign ownership, government ownership, revenue growth. Those are variables used by many authors when analyzing corporate profits. They are important factors influencing the estimation of variables affecting corporate financial performance.

Corporate size (SIZE). Bayoud et al. (2012) argue that large-scale enterprises are likely to generate more profits than smaller ones. Therefore, the size of enterprises is considered as an important factor affecting the relationship between corporate social responsibility disclosure and corporate financial performance.

Leverage (debts/equity) ( $L E V$ ). Financial leverage is used by research as a factor affecting corporate financial performance. Nguyen \& Dang (2017) argued that when a company is dominated by creditors, its financial performance may be affected. Therefore, financial leverage is necessary in the model to test the correlation between corporate social responsibility disclosure and corporate financial performance.

Foreign ownership (FRO). Foreign ownership is an important variable affecting corporate fianncial performance (Zeitun, 2014). Zeitun assumed that foreign shareholders coming from developed countries with higher profit orientation, they have expertises, experiences and management skills which help boostingcorporate performance. Similarly, a study of Nguyen \& Dang (2017) also concludeda positive relationship between foreign ownership and corporate fiancial performance

Government ownership (GRO). According to Doan \& Nguyen (2017) state-owned enterprises tend to have less incentive to maximize profits because their profitability and investment are guaranteed by the government. Therefore, GRO variable is necessary to consider the relationship between corporate social responsibility disclosure and corporate financial performance.

Revenue growth (GRW). In a study of Zeitun's (2014) on capital structure and corporate performance of Jordanian countries demonstrated that revenue growth has a positive effect on corporate performance. The author explained that corporates with high growth rate will have better results because they can have more investment opportunities and more profits.

\subsection{Data analysis}

To examine whether next year's financial performance has a positive relationship with corporate social responsibility disclosure of previous year, the author used the regression equation of dependent variable which is ROA and independent variable which is the level of CSRD and controlling variables as follows:

$$
\operatorname{ROA}_{i, t}=\beta_{\mathrm{o}}+\beta_{1} \mathrm{CSRD}_{\mathrm{i}, \mathrm{t}}+\beta_{2} \mathrm{SIZE}_{\mathrm{i}, \mathrm{t}}+\beta_{3} \mathrm{LEV}_{\mathrm{i}, \mathrm{t}}+\beta_{4} \mathrm{FRO}_{\mathrm{i}, \mathrm{t}}+\beta_{5} \mathrm{GRO}_{\mathrm{i}, \mathrm{t}}+\beta_{6} \mathrm{GRW}_{\mathrm{i}, \mathrm{t}}+\mathrm{u}_{\mathrm{i}, \mathrm{t}}
$$

Method of data analysis used in this study is GMM. The reason why the author chose GMM 
is that according to stakeholder theory and legitimacy theory, there is a two-way relationship between social responsibility disclosure and corporate financial performance. This statement was also demonstrated in the study of Ullmann (1985), Jitaree (2015). This results in an endogenous relationship between CSRDand ROA. Endogenous phenomena makesestimation unstable. To overcome this phenomenon, the author usedGMM developed by Arellano \& Bover (1995) and Blundell \& Bond (1998).

\section{Results}

\subsection{Descriptive statistics}

According to survey on the level of corporate social responsibility disclosure of 43 listed companies during the period from 2006 to 2016, the average level of corporate social responsibility disclosure has increased steadily from 2006 to 2016. This indicates that more corporate concern about corporate social responsibility disclosure as well as focus on long-term development goals and bring benefits to the community.

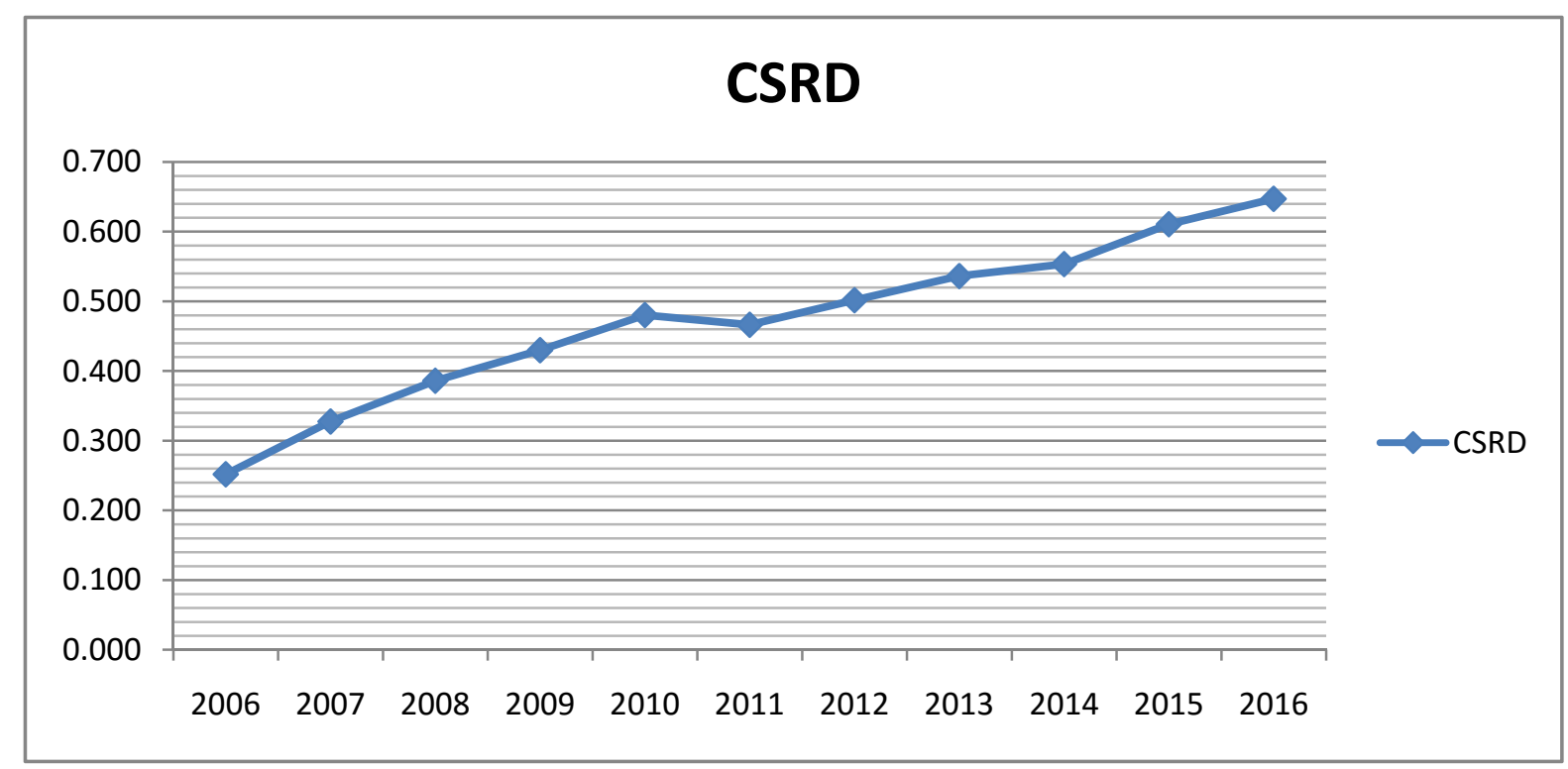

Source: created by authors

Figure 1. Average level of CSRD of enterprises during the period from 2006 -2016

Detailed information on average level of corporate social responsibility disclosure on environmental responsibility (ENV), employment responsibility (EMP), community responsibility (COM), responsibilities to customers (CUS) showed that the level of environmental information disclosure is the lowest. This means that Vietnamese enterprises do not pay much attention to environmental responsibility. The activities of waste discharge, pollution control in business process, strategies to support environmental protection activities have not received enough care from enterprises. This is the difference between Vietnam and developed countries in Europe, where enterprises focus on information disclosure on environment, energy, recycling, pollution due to pressure from customers and investors on the environmental protection actions of enterprises. Information about responsibilities to customers announced by most enterprises includes information on product quality, product safety, production process, product commitment. Enterprises want to use this information to 
promote their products to customers and also to show corporate responsibility towards products they provide.

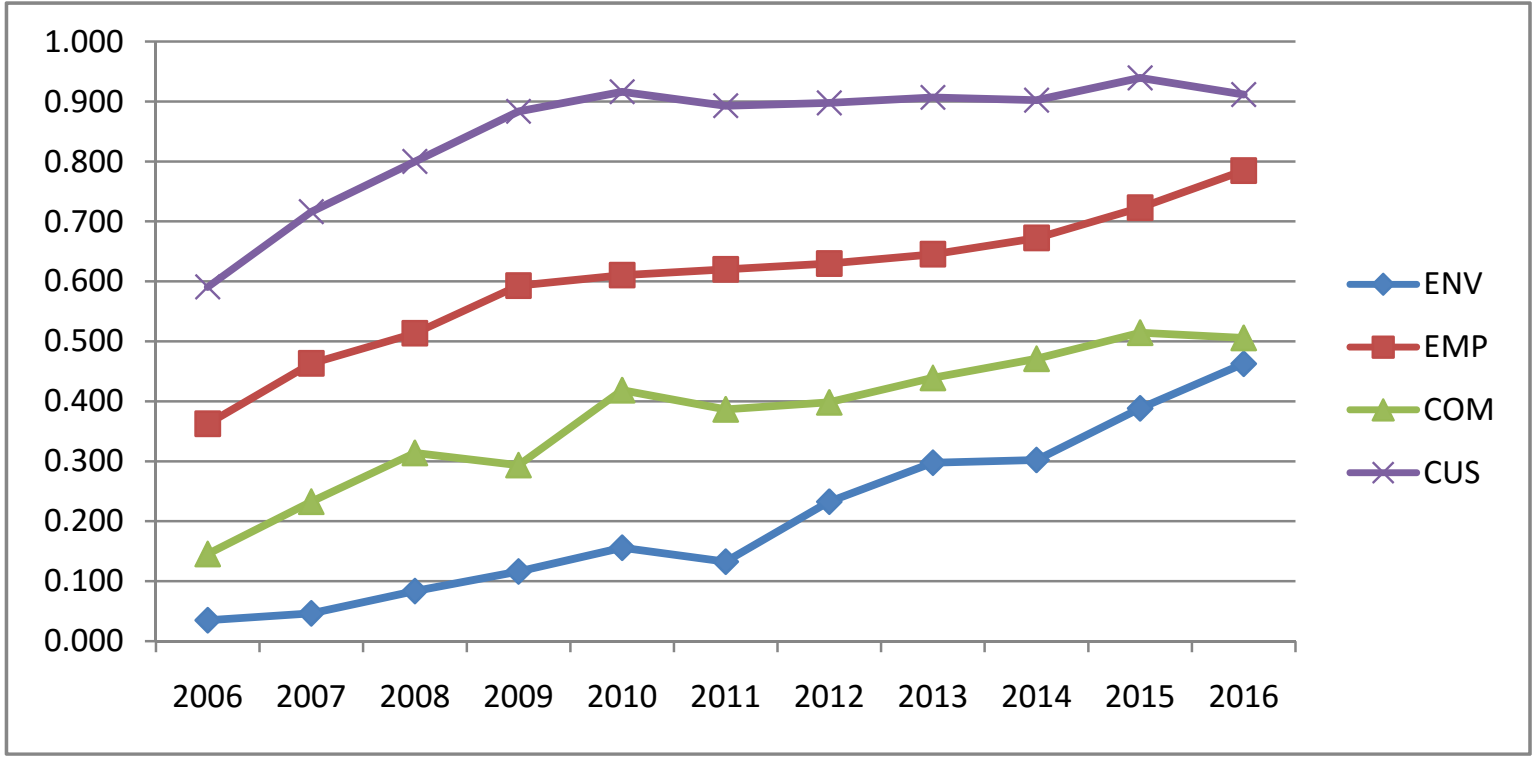

Source: created by authors

Figure 2. Level of information disclosure according to indicators of enterprises during the period from $2006-2016$

\subsection{Correlation analysis}

Table 3. Correlation coefficient among variables in the model

\begin{tabular}{|l|l|l|l|l|l|l|l|}
\hline Variables & ROA & CSRD & FRO & GRO & SIZE & LEV & GWR \\
\hline ROA & 1 & & & & & & \\
\hline CSRD & 0.4385 & 1 & & & & & \\
\hline FRO & 0.3525 & 0.488 & 1 & & & & \\
\hline GRO & 0.1005 & -0.0941 & -0.1842 & 1 & & \\
\hline SIZE & 0.0202 & 0.46 & 0.3797 & -0.1636 & 1 & & \\
\hline LEV & -0.4182 & -0.2684 & -0.2768 & -0.1024 & 0.18 & 1 & \\
\hline GWR & 0.1569 & 0.0148 & 0.0716 & -0.0352 & 0.0344 & -0.0414 & 1 \\
\hline
\end{tabular}

Source: calculation of authors based on Stata 12

Table 3 shows that corporate social responsibility disclosure in previous year has a relatively high correlation with ROA. This indicates that corporates with more information disclosure 
have better asset usage efficiency. In addition, table 2 also shows that return on assets is positively correlated with firm size, the rate of government ownership, the rate of foreign ownership and growth rate but it is negatively correlated with the ratio of debt on equity. This proves that high margin firms are large-scale enterprises with a high proportion of government ownership, high proportion of foreign ownership, high revenue growth rates and low debt-to-equity ratio.

\subsection{Regression analysis}

\section{Detecting multi-collinearity}

Authors used command if with model OLS and command vif, uncentered with model REM and FEM. Tables 4showed that in the model REM and FEM variables SIZE have coefficient VIF $>10$, with presence of multi-collinearity. SIZE variable will be discarded from the model.

Table 4. Detecting multi-collinearity of variables in the model

\begin{tabular}{|l|r|r|r|r|r|r|}
\hline \multirow{2}{*}{ Variables } & \multicolumn{2}{|c|}{ Model OLS } & \multicolumn{2}{c|}{ Model REM } & \multicolumn{2}{c|}{ Model FEM } \\
\cline { 2 - 8 } & VIF & \multicolumn{1}{c|}{$\mathbf{1 / V I F}$} & VIF & \multicolumn{1}{c|}{$\mathbf{1 / V I F}$} & \multicolumn{1}{c|}{ VIF } & 1/VIF \\
\hline SIZE & 1.58 & 0.611736 & 10.77 & 0.092864 & 10.77 & 0.092864 \\
\hline CSRD & 1.63 & 0.631599 & 3.8 & 0.263049 & 3.8 & 0.263049 \\
\hline FRO & 1.52 & 0.658508 & 3.5 & 0.285404 & 3.5 & 0.285404 \\
\hline LEV & 1.35 & 0.738728 & 3.11 & 0.322046 & 3.11 & 0.322046 \\
\hline GRO & 1.07 & 0.937104 & 2.59 & 0.386327 & 2.59 & 0.386327 \\
\hline GWR & 1.01 & 0.992073 & 1.16 & 0.86241 & 1.16 & 0.86241 \\
\hline & & & & & & \\
\hline Mean VIF & 1.36 & & 4.15 & & & \\
\hline
\end{tabular}

Source: Calculation of authors based on Stata 12

\section{Auto-correlation test}

Command xt serial was used to implement Wooldridge test with hypothesis Ho: there is no auto-correlation. The result showed Prob $>F=0.5122$, there is no evidence to reject Ho. There is no auto-correlation in the model.

\section{Heteroskedasticity test}

Tác giả dùng kiểm định Breusch-Pagan test was used with hypothesis Ho: there is no heteroskedasticity in the model OLS. Breusch and Pagan Lagrangian test with hypothesis Ho: there is $\mathrm{c}$ in the model REM. Modified Wald test with hypothesis Ho: there is no heteroskedasticity in the model FEM. The results in table5showed that heteroskedasticity exists in all models. 
Table 5. Summary of heteroskedasticity tests

\begin{tabular}{lllll}
\hline Model & Test & $\begin{array}{l}\text { Chi-squar } \\
\text { e statistic }\end{array}$ & $\begin{array}{l}\text { Pro }>\text { chi- } \\
\text { square }\end{array}$ & Test result \\
\hline OLS & Breusch-Pagan & 83.40 & 0.0000 & There is heteroskedasticity \\
REM & $\begin{array}{l}\text { Breusch and Pagan } \\
\text { Lagrangian }\end{array}$ & 140.87 & 0.0000 & There is eteroskedasticity \\
FEM & Modified Wald & 11435.69 & 0.0000 & There is eteroskedasticity \\
\hline
\end{tabular}

Source: Calculation of authors based on Stata 12

\section{Generalized Method of Moment(GMM)}

As discussed above, there exists an endogenous relationship between CSRD and ROA. Endogenous phenomena makes estimation unstable. To overcome this phenomenon, regression method GMM was used which was developed by Arellano \& Bover (1995) and Blundell \& Bond (1998) to solve this problem. In addition, GMM can solve problems of heteroskedasticity and auto-correlation. In GMM, it is necessary to distinguish between instrumented variable and instrument variable. If the variables are predicted to be endogenous, then they are classified as instrumented variables according to GMM and then only the last values of these variables are appropriate tools. If the explanatory variables are defined as exogenous extrinsic variables, they are grouped into the instrument variable group (iv_instrument variable). The rationale for the GMM test is shown in the Hansen test results to determine whether the equation has used enough variables to measure the difference. The hypothesis in Hansen's test is as follows: Ho is an exogenous variable, meaning that it is not correlated with the error of the model. The $p$ value of Hansen statistic $>0.05$ is not sufficient basis to reject Ho means that the tool is exogenous. Then the model with instrument variables are appropriate. In addition, if Hansen test is strong, the number of instruments must be less than or equal to number of groups. Arellano Bond test about the auto-correlation with hypothesis Ho: there is no auto-correlation. In Arellano-Bond test AR (2) if $\operatorname{Pr}>0.05$, we can include that there is no auto-correlation.

In order to implement GMM, authors used command: Xtabond2 with endogenous variable CSRD and selecting two step to make two-step estimation. The results are shown in the table 6as follows: 
Table 6. Regression result of GMM

\begin{tabular}{|l|c|c|}
\hline Variables & Coefficient $\boldsymbol{\beta}$ & P-value \\
\hline ROA $(-1)$ & 0.618209 & 0 \\
\hline CSRD & 0.033219 & 0 \\
\hline FRO & -0.00273 & 0.583 \\
\hline GRO & 0.026129 & 0 \\
\hline LEV & -0.0134 & 0 \\
\hline GWR & 0.050793 & 0 \\
\hline cons & 0.02455 & \\
\hline $\begin{array}{l}\text { Number of obs }=430 \\
\text { Number of groups }=43 \\
\text { Number of instruments } \\
=31\end{array}$ & $\begin{array}{l}\text { Sargan test of overid. restrictions: chi2(34) }=49.82 \operatorname{Prob}>\operatorname{chi} 2=0.039 \\
\text { Hansen test of overid. restrictions: chi2(34)=38.44Prob }>\text { chi2 }=0.275\end{array}$ \\
\hline
\end{tabular}

Source: Calculation of authors based on Stata 12

The results of GMM in table 6are appropriate. Table 6 shows that there is no auto-correlation as Arellano-Bond test AR (2) $\operatorname{Pr}>\mathrm{z}$ which is greater than $\alpha(5 \%)$. Furthermore, Hansen test shows that there is no endogenous phenomenon in the model as Prob $>$ chi 2 of Hansen test which is greater than $\alpha(5 \%)$. Besides, the number of instrument variables $=41<$ the number of groups of variables $=43$ which ensures that Hansen test is strong.

Regression results in table6shows that the level of influence of CSRD on ROA was $0.033 \%$ with a significance of $1 \%$. This result was also found in study of Jitaree (2015) and Ho \& Yekini (2014). The results of this study also showed that the debt-to-equity ratio negatively affects ROA with $0.013 \%$ with significance of $1 \%$ significance. It can be seen that in Vietnam, firms with high debt-to-equity ratios are often low-performing firms, therefore, when firms borrowing with high interests, their financial performance will be reduced. The results also showed that the proportion of government ownership has a positive influence on the efficiency of asset utilization with the coefficient $\beta=0.026$ at $1 \%$ significance. This shows that enterprises with government ownership in Vietnam have made great efforts in production process and had good results. Government investment in corporates has contributed corporate financial performance. In addition, regression result in Table 6 also shows that corporate performance depends on revenue growth. If the growth rate of enterprise revenue increased by $1 \%$, the asset usage efficiency used by enterprises increased by $0.05 \%$ with a significance of $1 \%$.

\section{Conclusion}

The regression results shows that coefficient $\beta=0.032$ and sig $=0.000$ in Table 6indicating that impact of CSRD of the previous year on ROA was positive and if the average score of CSRD increases by 1 point, ROA would increase by $0.032 \%$. Although the level of influence is weak, this shows a positive sign of practicing and disclosing of corporate social responsibility in terms of environmental responsibility, concern for workers' lives, investment in training and development of community, and specially, information on product quality has contributed to improving corporate performance. Many companies are afraid of costs and resources they must 
pay to implement and report corporate social responsibility, but the results of this research showed that the resources of enterprises will be offset because it brings benefits to enterprises such as improving the capacity of employees, attracting good workers, creating business opportunities for enterprises in new markets, creating prestigious image to the community, improving revenue, increasing brand value.

As a result, corporate financial performance depends on corporate social responsibility disclosure. Although the level of influence is weak, it also shows that if an enterprise has an investment strategy for implementing and disclosing corporate social responsibility, it can contribute a small part to the development of enterprises, especially in the new era of investment in sustainable development. However, the survey results also show that the level of corporate social responsibility disclosure of Vietnamese enterprises is low. For that reason, increasing of practicing and disclosing corporate and public disclosure of corporate social responsibility is imperative. Here are some solutions:

For the Vietnamese Government, it is necessary to develop a legal framework for the practice and disclosure of corporate social responsibility in Vietnamese legal system, and consider corporate social responsibility as mandatory in order to raise corporates' awareness for the sake of sustainable development. To achieve this, the Government should soon issue standards and codes of conduct for sectoral and national level on corporate social responsibility which depends heavily on the will and the interests of enterprises. Today, corporate social responsibility has become more common, more practical, and more encouraging for enterprises to implement with common standards and criteria. Vietnam has not yet developed a code of conduct for corporate social responsibility. A small number of enterprises, if they want to implement corporate social responsibility, find it very difficult to implement in a systematic way. It is, therefore, important to develop a set of corporate social responsibility standards based on international experiences while taking into account local conditions. Along with that is the independent, responsible corporate social responsibility rating system.

Step-by-step applying policy of corporate social responsibility disclosure: Annual or periodic reports on corporate social responsibility are not only a means of promotion, verifying quality but also an informational tool for owners, government, community and other stakeholders to consider and communicate information with enterprises. The application of corporate social responsibility reporting in Vietnam is a gradual process of institutionalization, both from the government and from enterprises and other organizations, and there may not sufficient conditions for most Vietnamese enterprises to apply in the short term. First of all, this reporting regime should be applied by large-scale enterprises and enterprises which have great impacts on society and environment, such as corporations and specially important corporations and listed companies.

Raising awareness of enterprises on corporate social responsibility has not yet been adequately concerned in Vietnam, in terms of perspective, content and implementation. Most enterprises do not have sufficient awareness of corporate social responsibility as well as its role in enhancing the capacity competition and sustainable development of their business, specially some consider corporate social responsibility as a burden of costs. In particular, people, communities, workers and consumers are more difficult to approach in this problem, while 
these are related parties who can promote corporate social responsibility. Therefore, the first thing to do is to continue to propagate and raise awareness of corporate social responsibility more strongly and in a broader scope and subjects, not just limit in the business community, enterprises but move to communities and localities, including general education programs. Enterprises and stakeholders need to be more aware of corporate social responsibility, especially in the context of ever-widening and deeper integration.

\section{Limitations and recommendations for future research}

Firstly, the research applied a content analysis method to measure the level of corporate social responsibility disclosure. Since corporate social responsibility is a broad category with many guiding standards, in the process of analyzing the authors did not rely on any standard but selectively chose regulations of Vietnam from previous studies to develop a new scale of social responsibility content of Vietnamese enterprises. Therefore, errors and subjectivity of authors are inevitable. The authors wish to be able to measure corporate social responsibility disclosure based on reports of corporate social responsibility of Vietnamese enterprises when regulations on this topic are standardized.

Secondly, GMM is appropriate with short data table with a short period of time but with a large number of firms. However, in this study the number of enterprises classified by sectors was too small, so the examination of the relationship between corporate social responsibility disclosure and financial performance of each sector could not be conducted. The authors wish to have further studies which can add different categories of sectors.

Thirdly, in this study, the authors only used the return on assets ROA as measure of financial performance. Future studies may use a variety of financial performance measures to supplement research results such as return on equity ROE, market value compared to book value Tobin'Q.

\section{References}

Aras, G., Aybars, A., \& Kutlu, O. (2010). Managing corporate performance Investigating the relationship between corporate social responsibility and financial performance in emerging market. International Journal of Productivity and Performance Management, 59(3), 229-254. https://doi.org/10.1108/17410401011023573

Arellano, M., \& Bond, S. (1991).Some tests of specification for panel data: Monte Carlo evidence and an application to employment equations. The Review of Economic Studies, 58, 277-297. https://doi.org/10.2307/2297968

Arellano, M., \& Bover, O., (1995). Another look at the instrumental variable estimation of error-components models. Journal of Econometrics, 68, 29-51. https://doi.org/10.1016/0304-4076(94)01642-D

Bayoud, N. S., Kavanagh, M., \& Slaughter, G. (2012). An empirical study of the relationship between corporate social responsibility disclousure and organizational performance:evidence from Libya. International Journal of Management and Marketing Research, 5(3), 69-82.

Blundell, R., \& Bond, S. (1998). Initial conditions and moment restrictions in dynamic panel data models. Journal of Econometrics, 87, 115-143. https://doi.org/10.1016/S0304-4076(98)00009-8 
Branco, M., \& Rodrigues, L. (2006). Corporate social responsibility and resource- based perspectives. Journal of Business Ethics, 69(2), 111-32. https://doi.org/10.1007/s10551-006-9071-z

Nguyen, T, N, B., Tran, T, T, H., Le, H, O., Nguyen, T, P., Trinh, H, T., \& Le, V. (2015). Association between Corporate Social Responsibility Disclosures and Firm Value-Empirical Evidence fromVietnam. International Journal of Accounting and Financial Reporting, 2162-3082. https://doi.org/10.5296/ijafr.v5i1.7394

Cheung, P., \& Mak, W. (2010). The relation between corporate social responsibility discosure and financial performance: envidence from the commercial baanking industry. Project submitted in partial fullilment of the requirements for the degree of master of financial risk management.

Deegan, C. (2002). The legitimising effect of social and environmental disclosures-a theoretical foundation. Auditing \& Accountability Journal, 15(3), 282-311. https://doi.org/10.1108/09513570210435852

Dewi, K., \& Monalisa, M. (2016). Effect of corporatr social responsibility discloure on financial performance with audit as a moderatin variable. Binus Business Review, 149-155. https://doi.org/10.21512/bbr.v7i2.1687

Doan, N. P. A., \& Nguyen, T. T. N. (2017). Factors affecting level of sustainable development disclosure of enterprises listed on the Vietnam stock market. The summary record of scientific conference Accounting- Auditing. QuyNhon University, pp. 384.

Dowling, J., \& Pfeffer, J. (1975). Organizational Legitimacy: Social Values and Organizational Behavior. Pacific sociological review, 18, 122-136. https://doi.org/10.2307/1388226

Dragomir, V. D. (2010). Environmentally sensitive disclosures and financial performance in a European setting. Journal of Accounting \& Organizational Change, 6(3), 359-388. https://doi.org/10.1108/18325911011075222

Edward Freeman, R. (1984). Strategic Management: A Stakeholder Approach. Pitman Publishing.

http://www.worldcat.org/title/strategic-management-a-stakeholder-approach/oclc/9685996

Gray, R., Kouhy, R., \& Lavers, S. (1995). Corporate social and environmental reporting: a review of the literature and a longitudinal study of UK disclosure. G Auditing \& Accountability Journal, 8(2), 47-77. https://doi.org/10.1108/09513579510146996

Gunawan, J., Djajadikerta, H., \& Smith, M. (2009). An examination of corporate social discloures in the annual reports of indonesian listed companies. Joural of asia pacific centre for environmental accountability, 13-39.

Ho, N. T. T., \& Yekini, L. S. (2014). Investigating the link between CSR and Financial performance-Evidence from Vietnamese listed companies.British Journal of Arts and Social Sciences, $17(1)$,

85-101.

http://www.bjournal.co.uk/volume/paper/BJASS_17_2/BJASS_17_02_02.pdf 
Ho, V. T., \& Ho, T. V. A (2017). Corporate social responsibility and fiancial performance : evidence of listed companies in Vietnam. Economics and development, pp. 36-43.

Jitaree, W. (2015). Corporate social responsibility disclosure and financial performance: evidence from Thailand. Doctor of Dowling, J \& Pfeffer, J. (1975). Organizational Legitimacy: Social Values and Organizational Behavior. Pacific sociological review, 18, 122-136.

Khlif, H.,Guidara, A.,\& Souissi, M. (2015) "Corporate social and environmental disclosure and corporate performance: Evidence from South Africa and Morocco", Journal of Accounting in Emerging Economies, 5(1), 51-69. https://doi.org/10.1108/JAEE-06-2012-0024

Lu, Y., Abeysekera, I., \& Cortese, C. (2015). Corporate social responsibility reporting quality, board characteristics and corporate social reputation Evidence from China. Pacific Accounting Review, 27(1), 95-118. https://doi.org/10.1108/PAR-10-2012-0053

Mahoney, L., \&Roberts, R. W. (2007). Corporate social performance, financial performance and institutional ownership in Canadian firms. Accounting Forum, 31(3), 233-53. https://doi.org/10.1016/j.accfor.2007.05.001

Makni, R.., Francoeur,C.. \& Bellavance, F. (2009). Causality Between Corporate Social Performance and Financial Performance_Evidence from Canadian Firms. Journal of Business Ethics, 409-422. https://doi.org/10.1007/s10551-008-0007-7

Mohammed,N.A., Zakaree,S., \& Oladele, O. K. (2016). Corporate Social Responsibility Disclosure and Financial Performance of Listed Manufacturing Firms in Nigeria. Research Journal of Finance and Accounting, 7(4), 47-58.

Nguyen, X. H., \& Trinh, H. T. (2016). Relationship between investmennt of sustainable development and financial results under quality control of finanical reports. Summary report of conference. Hanoi University of Industry.

Nguyen, T. K. C.(2016). Corportate social responsibility in Vietnam nowadays. Doctoral thesis. University of Social Sciences and Humanities, Vietnam national university.

Nguyen, T. M. H., \& Dang. T. L. (2017). Impact of ownership structure to performance of listed companies on the Vietnam stock market. Journal of Science Vietnam nationa university:Economics and business, No. 1. pp.23-33.

Platonova, E., Asutay, M., Dixon, R., \& Mohammad, S. (2016). The Impact of Corporate Social Responsibility Disclosure on Financial Performance: Evidence from the GCC Islamic Banking Sector.Journal of Business Ethics, 1-21. https://doi.org/10.1007/s10551-016-3229-0

Saleh, M., Zulkifli, N., \& Muhamad, R. (2011). An Empirical Examination of the Relationship between Corporate Social Responsibility Disclosure and Financial Performance in an Emerging Market. Asia-Pacific Journal of Business Administration, 3(2), 165-190. https://doi.org/10.1108/17574321111169849

Strouhal, J., Gurvits, N., \& Nikitina, K. M. (2015). Finding the link between CSR reporting and corporate finicial performance: evidence on Czech and Estonian list companies Central european business review, 4(3), 45-58. 


\section{Macrothink}

Asian Journal of Finance \& Accounting ISSN 1946-052X 2018, Vol. 10, No. 1

Tjia, O., \& Setiawati, L. (2012). Effect of CSR Disclosure to Value of the Firm: Study for Banking Industry in Indonesia. World Journal of Social Sciences, 2(6),169-178.

Ullmann, A. A. (1985). Data in search of a theory: a critical examination of the relationships among social performance, social disclosure, and economic performance of U. S. firms. The Academy of Management Review, 10(3), 540-557. https://doi.org/10.5465/AMR.1985.4278989

Vurro, C., \& Perrini, F. (2011). Making the most of corporate social responsibility reporting: disclosurestructure and its impact on performance. Corporate governane, 11(4), 459-474. https://doi.org/10.1108/14720701111159280

Zeitun, R. (2014). Corporate Governance, Capital structure and corporate performance: evidence from GCC Countries. Review of Middle East Economics and Finance, 75-96. https://doi.org/10.1515/rmeef-2012-0028 